\title{
Articles
}

\section{Teaching Canadian Culture: Teacher Preparation}

Robert Courchêne

With the transformation of cultural content from an add-on to an integral part of the K-Adult ESL classroom, L2 specialists must come to grips with three separate but related issues in the Canadian context: What is Canadian culture? How do we prepare teachers to teach Canadian culture? How do we teach about culture in the classroom? After presenting a new vision of Canadian culture that is to serve as a framework for deciding what to teach in the L2 classroom, I discuss three important pedagogical issues: (a) consciousness raising - making both teachers and students more aware of the origins and role of culture; $(b)$ teacher preparation-how adequately to prepare teachers to teach Canadian culture in a multicultural classroom; and (c) tolerance and conflicting visions-how to strike a balance between the dominant cultural paradigm and the new cultural knowledge and experience that arrives with each new Canadian.

\section{Introduction}

For many decades the oft repeated question, "What is Canadian Culture?" produced smiles or some statement about what it was not, the most frequent one being, "It is not American culture." With the passage of time, however, this question has taken on a much more serious tone. Our constant exposure to American culture through the media, books, and magazines, the ethnocultural diversification of our society resulting from our immigration policy along with its concomitant racist sentiments, the political tensions between Quebec and the other provinces in Canada, the state of the Canadian economy, the forces of regionalism in Canada, the claims by Canada's Aboriginal peoples for justice in the areas of land claims and self-government, and, finally, the absence of any effective policy to promote Canadian culture by the federal government have forced Canadians to search anew for the essence of their culture and identity. In most countries the concept of identity is the product of a common language, culture, and history. In China, for example, which is $85 \%$ Han Chinese, the inhabitants share a history, language, and culture that has existed for thousands of years. The 15\% minority population has little or no effect on the dominant culture. China's sense of its identity is clearly defined. 
In Canada this is certainly not the case. Canada is frequently described as a country with (a) two founding peoples, French and English, with different languages and histories and a partially shared culture; (b) Aboriginal peoples with a variety of languages histories and cultures, most of which have been excluded from the mainstream; and (c) a long tradition of immigrants from a wide variety of countries, languages, and cultures. As a result of its history, Canada has not had the advantage of having been able to forge a common destiny based on shared cultural and historical events. Canada has been, and remains today, a country of immigrants, with the exception of the Aboriginal peoples who have been here for thousands of years. We do not have a common language that everyone speaks. In fact, by the year 2000, according to Statistics Canada projections, $40 \%$ of all Canadians will have a language other than English or French as their first language. We do not have a long, common history. Contrary to what has happened in most countries - the victory of one group over another resulting in a unified history-the English after the defeat of Montcalm did not force the French to give up their language and culture; rather, the country evolved so that by the 1840s it was divided into Upper and Lower Canada along linguistic and religious lines. For the next 100 years the contact between the two languages and cultures was often limited. The large numbers of new Canadians who arrived at the turn of the century settled mostly in English Canada and were consequently only marginally influenced by the French language and culture.

Finally, we do not have a common culture shared by all. Although the dominant culture is based on Judeo-Christian values that have found expression in the laws, traditions, customs, institutions, and schools, an increasing number of new Canadians do not find many of these customs and traditions meaningful as they have no cultural memory of them tied to some previous historical event or figure (Nora, 1984). In addition, although agreeing to respect the law and the Charter of Rights and Freedoms, they do so not for moral or religious reasons, but as part of the act of becoming new Canadians. Many believe that the attraction of becoming a Canadian is being able to keep one's own culture and identity and still participate fully in Canadian society. Being a Canadian does not mean having to define oneself solely in terms of the dominant culture.

Trying to define Canadian identity and culture in such a dynamic sociocultural milieu is difficult to do. Yet in many language and other subject matter programs today, culture has evolved from being an add-on to a central component in the curriculum. For example, in The Common Curriculum: Policies and Outcomes (Ministry of Education and Training, 1995), the new blueprint for education for grades 1-9 in Ontario, students are expected to acquire an extensive knowledge not only of Canadian culture, but also of the cultures of other students in their class as a means of "understanding 
diversity and valuing equity." This decision to teach culture in a systematic and integrated manner implies that somewhere a sufficiently precise definition of Canadian culture exists to allow curriculum planners to identify its components. It further assumes that one is able to describe these components in sufficient detail that they can become the content of a common curriculum, an integrated teaching program. Finally, it implies that we can train or show people how to teach culture, even when that culture is not their own.

\section{Canadian Culture: Framework for a New Vision}

In the literature many definitions of culture exist from a wide range of perspectives: anthropological, behavioral, cognitive, sociological, and phenomenological. Rather than provide a series of representative definitions, I present a summary of the characteristics of culture based on the work of Damen (1986, pp. 88-89).

1. Culture is learned. If it can be learned, it can be taught and acquired.

2. Cultures and cultural patterns change. It is more important to learn about how to learn a culture or adapt to these changes than to learn the "fact" and "truths" of the moment.

3. Culture is a universal fact of human life. No human group or society is without culture. Cultural patterns and themes are related to universal human needs and conditions.

4. Culture provides sets of unique and interrelated, selected blueprints for living and accompanying sets of values and beliefs to support these blueprints. Strong networks of relationships and meanings link these relationships and value systems. These networks provide life support systems for those who interact within them.

5. Language and culture are intertwined and interactive. Culture is transmitted in great part through language; cultural patterns are in turn reflected in language.

6. Culture functions as a filtering device between its bearers and the great range of stimuli presented by the environment. The filtering device is both protective and limiting. Intercultural communicators must traverse the boundaries of their own filtering systems or screens and enter the systems of others.

In trying to define and teach Canadian culture, Damen's six points are of critical importance. The fact that culture is teachable means that it can be systematically integrated into the curriculum in both explicit and implicit ways. The fact that it is universal, but ever changing, means an ethnic group's, a society's, a country's culture is constantly evolving unless means are taken to prevent such evolution (e.g., banning satellite dishes, censoring the press and films, writing books from a given perspective). The fact that it is exclusive means that choosing to adhere to the cultural canon of a single group cuts one off from contact with other groups and, by corollary, living in 
several cultures requires more time, understanding, and flexibility. Finally, the fact that cultural patterns change means that any understanding of what Canadian culture is today will require an inclusion of the forces (and the content) from the past that have created it (Frye, 1975). Canadian culture in the 1990s is not the same as it was at the time of Confederation nor even at the turn of the century prior to the beginning of massive immigration. It is vibrant, dynamic, and ever becoming; consequently, it cannot be completely defined.

Schein (1985), based on research in organizational cultures, has identified six important components or overlays (see below) of any culture. Although for each component I have included only a small number of examples from Canadian culture, ${ }^{1}$ it would be possible to prepare a list similar (in form but not content) to Hirsch's (1987) cultural literacy list for Americans (Figure 1).

In commenting on these components, Schein (1985) along with Owens and Steinhoof (1989) have stated that although people are certainly able to list important dates in their country's history or their most popular traditions, they are frequently unable to articulate the values and beliefs, and sometimes norms, underlying their culture as these were learned through the process of enculturation and are now operating at the subconscious level. Consequently, it is frequently difficult to arrive at a detailed description of all six components and, therefore, of a culture as a whole.

Even if one were able to provide a detailed list for the above six categories-attempts have already been made to do this ${ }^{2}$ - a number of problems remain with such lists. First, in terms of norms, one would have to identify norms that shape the behavior of different groups in society; such groups would include firefighters, teachers, politicians, men, women, and so forth. Although some norms would be common to all, others would be culture specific, culture being used here to included more than just people from a single ethnic group. Second, and more critical, whose culture, whose values, whose traditions would be included in such a list? Culture in Canada is strongly influenced by both class and geography. There are important cultural variations in traditions, norms, and values from one part of Canada to the other and from urban to small-town or rural Canada. For example, Canada: A source book for orientation, language and settlement workers (Government of Canada, 1991) was supposed to provide new Canadians with an overview of Canadian culture. It was criticized by a large number of new immigrant groups, ESL teachers. For example, the text reports that Canadians do not urinate in public. This is not the case; Canadians frequently stop along the side of the road to relieve themselves. Young children are allowed to urinate in public. Anyone who has gone cross-country skiing or has been around an outside rink can bear witness to the existence of yellow snow; hence mothers' admonition to children, "Don't eat the yellow snow!" No single cultural practice regulates such behavior in public. The same could 


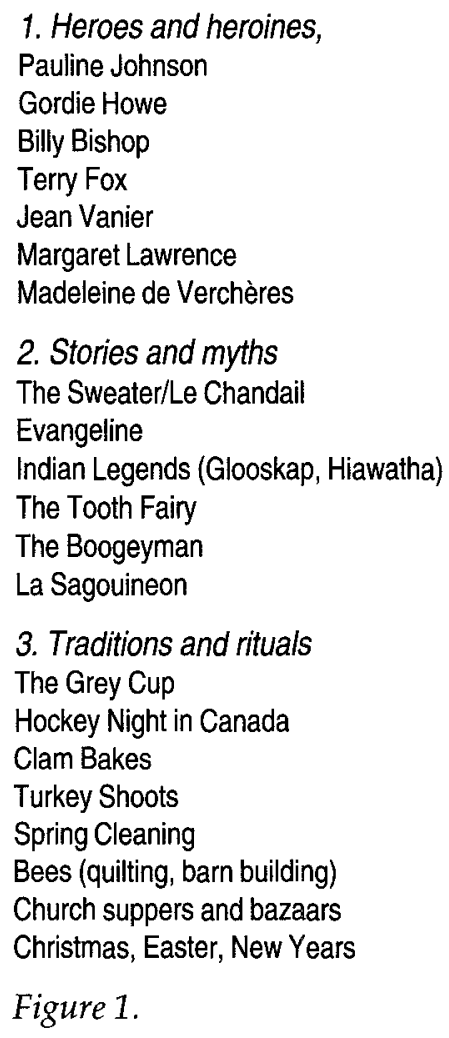

\section{Figure 1.}

\section{Behavior norms}

Stand in line for buses, tickets, concerts, etc.

Respect public property

Be punctual for work and appointments

Treat older people with respect-give them

seat on the bus, open doors

\section{Values and beliefs \\ Tolerance \\ Multiculturalism \\ Biculturalism \\ Peace \\ Spirit of compromise \\ Time as a precious commidity, a nonrenewable resource}

also be said for spitting, blowing one's nose without a handkerchief or tissue, or washing one's hands before meals or after visits to the toilet. A great deal of cultural variation exists within Canada's borders.

Third, there has been a gradual shift in Canadian society in terms of the basis for commitment to the laws and constitution and for partaking in long-established traditions. As new Canadians of other faiths and cultures arrive in Canada and agree to abide by our constitution and Charter of Rights and Freedoms, their commitment is not necessarily based on the JudeoChristian values that originally shaped these laws; rather, their commitment is a legal one, a personal one. In most cases they do not see any conflict between accepting to live by the Canadian laws and charters and keeping their own moral, spiritual, and cultural values. For example, many new Canadians are adopting the traditions of Christmas and Easter, not for religious reasons, but more as a result of commercial and family pressures (young children like to belong, to share in the world of other children their age); they have no religious attachment to them and, therefore, no cultural 
memory of these traditions. In most cases their commitment is not founded on values and beliefs, but on cultural participation-a desire to belong more fully (in China, I saw a similar process with the more affluent Chinese beginning to buy Christmas gifts even though it was not part of their culture). However, nothing prevents this original commitment from becoming tied to underlying beliefs and values at some future date.

Fourth, we have a series of competing or parallel cultural traditions fostered and financially supported by the multiculturalism policy of the federal government without any specific guidelines concerning the value or weight such new traditions should be given vis-à-vis existing traditions. In the interaction between the dominant culture and these new cultures, these new ways of being Canadian, we find the origin of many positive and negative forces in Canadian society as a whole, and in the classroom in particular. These new cultural visions offer members other ways of partaking in the society without accepting its cultural vision and underlying values and beliefs (Kymlicka, 1992).

Fifth, according to postmodern cultural philosophers such as Giroux (1992, 1993, 1994), culture is dynamic, rooted in a specific social context, subject to innumerable historical forces. It is not some reified body of knowledge transferred from one generation to another untouched by the forces of history. For each new generation the cultural paradigm must be reworked in the context of the changing society. Although he readily admits the importance of the past in forming and informing the cultural canon of any country, Giroux insists that the cultural canon must be constantly reshaped. In practice this means that any definition of Canadian culture must include (a) forces from the past that have shaped our existing cultural vision, a vision that new Canadians need to be familiar with if they are to understand "how Canada works"; (b) forces that we have systematically excluded throughout our history-people of the First Nations, Métis, Afro-Canadian, Chinese; and (c) new visions that are arriving with new Canadians from around the world. If, in the search for a new vision, all participants are given voice, the resulting cultural paradigm will be more than the sum of the parts. It will be a vision that reflects the existing and historical contexts.

This new common ground, therefore, cannot be Canadian culture as it was 100 years ago, for that would be a vision of culture as museum. Nor can it be a simple combination of the cultures and traditions of new Canadians plus existing traditions, as their traditions also changed in being transported and lived out in our culture. Somalian culture, for example, cannot be transported and inserted into the Canadian context without some form of adaptation (minimally) at the level of symbols, rituals, stories, and traditions. To be viable Canadian culture must be a synthesis of the past and the present, the old and the new, but never the reified and the fossilized. 


\section{The New Cultural Vision}

I believe that the new vision of culture will have to contain the following elements. First, it will have to reflect Canada's past. It will have to explain to new Canadians why we are who we are today; consequently, it will have to identify the forces that have shaped our culture, and these forces will certainly include many of the Judeo-Christian values and beliefs. We need to explain why we have laws against discrimination on the basis of gender, sexual orientation, or physical or mental capacity, why we do not permit female circumcision, why we allow abortions even though many people still object on religious grounds. As Delpit (1988) and Cummins (1989) have pointed out, knowledge is power; failing to provide new Canadians with knowledge of how our society and culture function is a way of denying them access to power, to high-paying and influential professions.

Second, it will have to be a vision that is built around a series of common rights and freedoms, a vision that adheres to the view of our country as represented in our constitution, but also a vision that allows for people and groups to belong to the country in different ways. In its most basic form, this may mean that although all Canadians agree to abide by the constitution and charter, they will do so for their own reasons and not because of some commonly held system of values. This would be close to what Delpérée (1995) called a citoyenneté objective-a citizenship based on submission to the laws of the country rather than one based on common culture, history, and language.

Third, it will have to be a vision that explains why we have not given equal voice to many groups in our society, how we have degraded others, and how we intend to rectify the situation. It is imperative that we recognize the importance of (wo)man's relationship to nature, to teach respect for the land that is central to Aboriginal culture; to recognize the enormous contributions made to Canadian art and sculpture by the Inuit; to recognize the contributions of Afro-Canadians to our history and culture; to acknowledge the work ethic and value placed on education by the Asian communities; to seek forgiveness and reconciliation from the Japanese community for their incarceration during World War II.

Fourth, it will be a vision that will be reflected in some common traditions and symbols (Canada Day, the flag, the RCMP, the CBC, the climate) as well as regional and culture-specific traditions.

It will take time both for new Canadians to adopt the existing symbols and traditions as their own and for Canadians who have been here for generations to accept new traditions, but it is happening. In the same way that many new Canadians have taken to hockey and skating, Canadians of long standing have come to accept and play soccer in large numbers. Many food dishes introduced by people from different countries are now part of 
Canadian palate-Chinese, Indian, Middle Eastern. As the introduction or elimination of new symbols or traditions is often seen as an erosion or change of the cultural values underlying the dominant paradigm, there is frequently conflict associated with such changes; that is, wearing a turban in Legion halls, reference to God in the opening prayer for parliament, removal of many explicit Christian references or symbols. Our vision will need to include strategies for managing such conflict.

It will have to be a vision that is supported and fostered by all levels of government through laws, institutions, cultural events, and education. Recent publications by both the government (Special Issue of TESL Talk, A Look at Canada, Heritage Moments, More of a Welcome than a Test, The Common Curriculum, Heritage Post: A Newsletter for Teachers) and ESL publishers (Being Canadian: Language for Citizenship; Canadian Concepts, Alternatives, Bridge to Fluency, Take Part: Speaking Canadian English) combined with existing cultural events mark the beginning of this process, but much remains to be done to present a more coherent vision of Canadian culture.

Finally, it will have to be a vision that is forever in transition, a vision on the way to becoming but never reaching its destination. As long as we as a people decide that we would like to open our country to new Canadians from around the world, we will be opening our doors to new ideas, new customs, new values, in short to new ways of being a Canadian.

\section{Teaching Canadian Culture: Pedagogical Issues}

Providing K-Adult-ESL-classroom teachers with a list of entries under Schein's (1985) six categories mentioned above or giving them a copy of the new vision will not be sufficient to enable the teaching of culture in a systematic way in the classroom. Many important questions must still be addressed.

1. How do we make all our students more conscious of culture and its role in our lives?

2. How do we prepare teachers to teach this new cultural vision?

3. Whose culture, whose values, whose traditions do we select for presentation?

4. What weight do we give to different aspects of our culture? If we have limited time, what do we choose from the bank of items?

5. What weight do we give to the new cultural paradigms (e.g., Somalian culture) as opposed to the dominant paradigm? Do we need to give all cultural paradigms equal time in class? If not, what criteria do we use to decide what will be included? 


\section{Consciousness-raising}

One of the most difficult problems faced by ESL teachers who want to integrate culture into their classroom is being able to explain and present it in an adequate manner, especially those aspects that are buried in the subconscious. If culture is going to be more than a list of do's and don't's, teachers must be able to explain to students, especially new Canadians, why we act and think the way we do. For example in common sayings such as "Cleanliness is next to Godliness," "Time is money," and "The early bird gets the worm," we have encapsulated important values, beliefs, and assumptions of our culture. If questioned by newcomers to Canada, many Canadians would not be able to provide an adequate explanation of these sayings. As a first step prior to teaching others about Canadian culture, teachers must upgrade their own knowledge about Canada and its culture. We cannot teach what we do not know ourselves.

Although some attempts have been made provide teachers with descriptions (LeBlanc, Courtel, \& Trescases, 1990; LeBlanc, 1990; Gouvernement du Québec, 1981, 1990, 1994), teachers have not always been provided with suggestions for raising cultural consciousness. Some exceptions do exist. In a document produced by the MAICC (1994) in Québec, the Ministry first presents a list of cultural values that people who choose to live in Québec need to be familiar with and then outlines a four-step consciousness-raising procedure (Morasse, 1995):

1. Ask new residents to observe the day-to-day behavior of Quebecois as it relates to one of the nine values identified (e.g., respect for the environment) and then to discuss their observations and insights.

2. Compare their observations and insights with the true state of affairs to temper their judgments.

3. Lead them to reflect on the meaning of the observable behavior by tying it to the underlying values.

4. Draw their attention to the legal consequences of unacceptable behavior; tell them about their rights and responsibilities and resources as a citizen.

Although such process a does not necessarily provide learners with lived experience or guarantee they will internalize the new cultural values, it leads them to reflect on their own and the host cultures. It makes them more aware of the commonalities that underlie the two cultures and how the differences can be bridged.

From a slightly different perspective, researchers such as CrawfordLange and Lange (1984), Seelye (1984), Damen (1986), Bailey (1991), ${ }^{3}$ and York (1991, 1992) have provided an extensive list of both techniques and resources that can be used to promote cultural consciousness and understanding. They include some of the following:

1. case studies and contrastive studies of cultural events; 
2. critical incidents: a focus on cross-cultural problematic, situations;

3. culture capsules and culture clusters;

4. simulations;

5. role plays;

6. culturgrams;

7. stories (literature) and films.

The aim of such techniques is to place learners in the situation of the other, to help them live the experience of the other and, as a result, gain a deeper understanding of how he or she feels. The type of technique used in the classroom may vary greatly with the age, language level, and educational background of the learners.

Related to this is the need for information for teachers to be able create possible links between the cultural heritage of newly arrived Canadians and the existing cultural paradigm. To do so, teachers need to be knowledgeable about the cultural backgrounds of their students. For example, the cultural profiles on China, Somalia, Guatemala, Lebanon, and so forth, prepared by the Catholic Immigration Centre in Ottawa, are excellent initiatives in this direction. Teachers need to be able to build bridges between the cultural heritage of the children and Canadian culture, to emphasize the similarities as much as possible. They need to become cross-culturally sensitive to avoid causing harm to students in their classes. Being able to do this requires specialized knowledge and training that to date has not been taught in any systematic way in many teacher training programs at the faculties of education. To conclude, the major problem in raising the cultural consciousness of both teachers and students is not the lack of resources, but the lack of political will to make the training for, and the teaching of, multicultural education a high-level priority.

\section{Teacher Preparation}

To ask if teachers, native and nonnative speaking, can be cultural interpreters is really begging the question; they have been performing this task for almost as long as language teaching has existed. What we are asking is how all ESL teachers can be trained to be more effective interpreters of cultural knowledge and, as a result, better prepared to help their students learn new cultural knowledge. The first set of problems is related to how cultural knowledge is learned in L2 or foreign language contexts. In the process known as acculturation, students acquire new knowledge through different forms of interaction: interaction with text (e.g., reading a history book about Canada); interaction with individuals, small and large groups; interaction with knowledge stored in long-term memory though synthesis, inferencing, and reflection. Although direct methods of teaching can be effective for teaching students facts and observable practices about culture, how do we go about teaching teachers how to help students become conscious of the under- 
lying values, especially if Schein (1985) is right in claiming that it is hard to describe these underlying values in a precise way? Furthermore, if such values are acquired through repeated episodes in authentic contexts, how do we train teachers to create such learning contexts? This problem is compounded for nonnative-speaking teachers who are not familiar with our Canadian culture. (They may have an advantage, though, in terms of being more open and more knowledgeable about the whole acculturation process.) Although not exhaustive in nature, I believe that the suggestions below would constitute a first step in instituting important changes in teacher training.

First, new courses must be developed that will provide teachers with an opportunity to (re)explore Canadian culture, multiculturalism, and to provide teachers with direct cross-cultural experience (Orr \& Finney, 1995). Many teachers leave the faculty of education without ever having taken a course in Canadian history. How are they going to be able to teach Canadian culture in the classroom, to talk about the contributions of various cultural groups to our society-knowledge essential to building bridges between the culture of new Canadians and Canadian culture - to explain to students the forces and events that have shaped Canadians into what they are today? ESL teachers need to know their own culture before they can share it with others.

A course (at least a module) on multiculturalism and antiracist education must become part of preservice training. First, teachers must be made aware of their own beliefs concerning race and culture. Teachers who have grown up as part of the dominant majority "simply see themselves as 'normal,' others as 'culturally diverse'" (Fried, 1993). This can be done using a number of the techniques suggested above for teaching students cultural knowledge, as well as the type of cultural analysis by used by Giroux (1994) to make student more aware of how films, advertisements, and texts are written from different perspectives, how they include some voices and exclude others. As well, teachers must learn how to set up antiracist classrooms, how to combat racism, and if it does occur, how deal with it through conflict resolution. In a multiculturalism and antiracist course at my university, we provided students with this training by inviting representatives from different stakeholders in the community-Multicultural Liaison Officers, immigration services, and local cultural communities, experts in multicultural and antiracist curriculum. Each dealt with a different aspect of the problem by providing students with both knowledge and training - simulation games, film, culture capsules. Students had to keep a reflective journal and prepare a culturgram based on interviews with a small groups of people newly arrived cultural group in Canada. For many participants who had to confront race and racism for the first time in any systematic way, the course made them realize how insular their education had been. 
In terms of cross-cultural education, courses similar to those developed at that University of Regina hold great promise for increasing teacher trainees' contacts with people from other cultures. Orr and Finney (1995) had students

gather first hand experience in cross cultural situations as a way to personalize social justice issues, shatter stereotypes and begin the development of culturally behaviours ... Underpinning this decision was the belief that social changes results from social interaction, not simply from more accurate knowledge and "better behaviors." (p. 30)

The student volunteers worked with different Aboriginal groups in the city of Regina. Throughout the course the student teachers had to keep journals to reflect on critical incidents, to record their feelings as they interacted with different members of the Aboriginal community. According to the authors, such direct experience provided a first step in breaking stereotypes, in helping students understand what it means to be a minority, and in appreciating Aboriginal people and their culture.

Second, all teachers should be required to spend at least one practicum in a multicultural classroom. This is especially critical for future teachers from urban and rural centers who have been schooled in predominantly white classrooms. I know from talking to candidates at our Faculty of Education that students from small towns found urban multicultural classes challenging to handle. In addition, where possible, such students should be given mentors from different racial and cultural groups. The opportunity to interact with these mentors and to discuss curriculum and classroom management with them will provide these teachers with an invaluable experience.

Third, in the teacher observation/supervision part of the program, special attention should be paid to cultural knowledge and behaviors. With observation grids such as FOCUS (Fanselow, 1987), it is possible to isolate a specific teaching variable for special consideration. Having students concentrate on these variables would make them more conscious of their importance in the classroom; it would also enable teacher trainers to offer trainees more focused feedback.

Fourth, teachers need extensive practice in preparing teaching materials for multicultural classrooms. They also need to analyze the underlying cultural values, beliefs, and, if possible, assumptions of the materials they select for use with their students. This analysis can be carried out using a variety of grids that have been developed for text analysis. Of equal importance, however, is the need to analyze critically popular culture that is being used with increasing frequency in the classroom, especially with the availability of such material on the Internet. Giroux (1994), in his discussion of the World of Disney and Benetton, provides excellent examples of how to deconstruct popular culture to get at the underlying meanings. In struggling to understand cultural bias in materials, student teachers will acquire not only a 
better knowledge of the target culture, but also of their own. They will be able identify role and gender stereotypes, racial overtones, sexist language, and motivated omissions.

Fifth, teachers in TESL/TEFL programs should be encouraged to keep culture logs that could be shared and discussed in either small groups or in the class as a whole as part of a reflective seminar. This approach has already been used successfully in the Access Program (a special on-site program for foreign-trained teachers who need an Added Basic Qualification to be able to teach in the Ontario school system; $\mathrm{Xu}, 1994)$ and the $\mathrm{L} 2$ language program at my university (Courchêne, 1994). In such logs and the ensuing discussions, teachers explore and express cultural ideas related to the host culture in a secure and supportive atmosphere. This type of dialogue could also be maintained with the same guarantees of privacy through e-mail or some other form of electronic transfer of information.

\section{Tolerance and Conflicting Cultural Visions}

One of the most difficult problems teachers face on a daily basis is how to strike a balance between what they perceive should be taught in terms of Canadian culture-they realize students are going to need this knowledge to succeed in society - and the integration of cultural knowledge from students from other countries, also part of Canadian culture. Many teachers are no longer confident or comfortable teaching Canadian traditions such as Christmas and New Year's for fear that they may be accused of not giving equal time to all cultural traditions in the classroom or for fear that they may offend; that is, being asked to take down the Cross on stage for Remembrance Day because it is a Christian symbol and offends students from other faiths. As Canadians, do we not have the right to use this symbol as it is closely tied to our culture and history? Do we not have to right to teach our traditions?

I believe that not only do teachers have the right to teach and integrate Canadian traditions into their curriculum, they have a responsibility to so for many reasons. First, many new Canadians have freely chosen Canada as their new home. They want to learn about their new country, its people, its traditions, its resources. They need this knowledge if they are going to be able to fit into Canadian society. Second, new Canadians ask many questions. Why do you plug your cars in at night? Why is it important to arrive on time? Why do you line up for buses? What should I bring if I am invited for dinner? How do I greet people? As a first step, new Canadians need to be taught the assumptions of culture as a kind of a safety net to avoid embarrassing themselves and others. With time, they must also be taught or placed. in situations where they can learn about the underlying values of our culture; to learn what has made us how we are today. 
In practice, this means that we should present traditions such as Christmas. We need to explain to new Canadians the religious origins of this tradition, how it is celebrated in different Christian traditions in Canada. We need to explain how Christmas, along with many Christian traditions, has been commercialized, how for many people it has lost its religious value while still retaining a humanistic value; it is a time of fellowship, a time to forgive and start anew. It would then be possible to go on to talk about Santa Claus, gift giving, and so forth. Once this has been done, the teacher can then ask students to share similar traditions of their own countries, focusing on what we all share in common and, if possible, adding new traditions to the celebration of Christmas in class. Teaching Canadian culture in the classroom does not mean that we cannot also teach or celebrate some of the important traditions of our Chinese, Somalian, or Vietnamese students. On the contrary, universal traditions such as New Year's provide excellent opportunities for sharing our cultural knowledge.

\section{Conclusion}

Defining Canadian culture and preparing L2 teachers to integrate it in a comprehensible and relevant way in our multicultural classrooms is certainly one of the greatest challenges our profession has faced in the last few decades. Because as L2 teachers we are often the first contact for new Canadians, we need to ensure that our students are provided with a balanced and in-depth view of the content of Canadian culture, a vision that will include not only visible manifestations, but also underlying explanations. To be able to do this effectively we must begin to discuss topics such as Canadian culture, multiculturalism, and racism in an open and healthy manner. We must be able to question our multiculturalism policy without being regarded as racist. We must be able to challenge the dominant cultural paradigm without being regarded as "unCanadian." We must be able to raise the questions that need asking so that we can prepare better and more informed Canadians for the 21st century.

\footnotetext{
Notes

${ }^{\mathrm{I}}$ The examples for this paper came from surveys of students in the Second Language Bursary Programme studying English and French, Anglophones in a high school bilingual program, students enrolled in the BA Programme in Second Language Teaching and teachers in all types of adult ESL programs. In each case, the participants were asked to write down 10 things that came to mind when they thought about Canada. The data has not yet been statistically analyzed.

${ }^{2}$ Descriptions of Canadian culture can be found in TESL Talk: Special issue on ESL and citizenship, More of a welcome than a test, a film produced for the Department of the Secretary of State of the Government of Canada, A Look at Canada, a booklet designed to provide new Canadians with information for citizenship, Canada: A source book for orientation, language and settlement workers an attempt by the federal government to explain Canadian culture as well as the catalogues of films, video and text funded by Multiculturalism Canada on the different linguistic, racial and cultural
} 
groups in Canada. Canada Post's series entitled Heritage Post: A newsletter for teachers is also an excellent source of both text and visual information on Canadian history. In addition to the government sources, publishing houses such as Prentice-Hall (Canadian Concepts and Take part: Speaking Canadian English) and Marcel Didier (Alternatives) have produced series with extensive Canadian content.

${ }^{3}$ The books by Bailey and York are of particular interest. In her book entitled Start-up Multiculturalism, Bailey provides the teacher with numerous suggestions both methodological and resource for integrating Canadian culture into the classroom. The activities in the book could be used from K-Adult with a minimal amount of adaptation. In Roots and wings: Affirming culture in earch childhood programs, York provides a comprehensive program of activities along with a guide to help teachers set up a multicultural curriculum; the Trainer's Guide is designed for teacher trainers to help them show teachers how to set up effective multicultural classrooms.

\section{The Author}

Robert Courchêne is the Interim Director of the Second Language Institute at the University of Ottawa. His areas of interest include classroom-centered research, teacher training, and multicultural education.

\section{References}

Bailey, C. (1991). Start-up multiculturalism. Pembroke: Pembroke Publishers.

Berish, L., \& Thibaudeau, S. (1992). Canadian concepts. Scarborough, ON: Prentice-Hall.

Cameron, J., \& Derwing, T.M. (1996). Being Canadian: Language for citizenship. Toronto, ON: Prentice-Hall.

Crawford-Lange, L., \& Lange, D. (1984). Doing the unthinkable in the second language classroom. In T. Higgs (Ed.), Teaching for proficiency: The organizing principle. Lincolnwood: National Textbook Company.

Courchêne, R.J. (1994). Dialogue journals and teacher education: A window on the past, present and future. Mosaic, 1(4), 1-5.

Cummins, J. (1989). Empowering minority students. Sacramento, CA: California Association for Bilingual Education.

Damen, L. (1986). Culture learning: The fifth dimension in the language classroom. New York: Addison-Wesley.

Delpit, L.D. (1988). The silenced dialogue: Power and pedagogy in educating other people's children. Harvard Educational Review, 56, 379-385.

Delpérée, F. (1995, June 1-2). Identité nationale et mondialisation, (version préliminaire). Colloque Langues, cultures et valeurs au Canada à l'aube du XXième siècle, Ottawa.

Engkant, L.P., \& Brady, K. (1986). Take part: Speaking Canadian English. Scarborough, ON: Prentice-Hall.

Fanselow, J. (1987). Breaking the rules. White Plains: Longman.

Fried, J. (1993). Building emotion and intellect: Classroom diversity in process. College Teaching, 41(4), 123-128.

Frye, N. (1975). Canada: New world without revolution. In R.H. Hubbard et al. (Eds.), Preserving the Canadian heritage (pp. 15-28). Royal Society of Canada Fourteenth Symposium. Ottawa: Royal Society of Canada.

Gagné, A., Pagurek, J., \& Fitzgerald, B. (1987). Alternatives. Montreal, PQ: Marcel Didier.

Giroux, H. (1992). Border crossings: Cultural workers and the politics of education. New York: Routledge.

Giroux, H. (1993). Living dangerously: Multiculturalism and the politics of difference. New York: Peter Lang.

Giroux, H. (1994). Disturbing pleasures: Learning popular culture. New York: Routledge. 
Government of Canada. (1988). The act for the preservation of multiculturalism in Canada. Ottawa: Multiculturalism, Secretary of State.

Government of Canada. (1991). Canada: A source book for orientation, language and settlement workers. Ottawa: Employment and Immigration Canada.

Government of Canada. (1995). A look at Canada. Ottawa: Citizenship and Immigration Canada.

Gouvernement du Québec. (1981). Autant de façons d'être Québécois: Plan d'action du gouvernement québécois à l'intention des communautés culturelles. Québec.

Gouvernement du Québec. (1990). Au Québec pour batîr ensemble: Énoncé d'un politique en matière d'immigration et d'intégration. Québec: Ministère des Communautés culturelles et de l'Immigration.

Gouvernement du Québec. (1994). Programme générale d'intégration linguistique: document de travail. Québec: Ministère des Affaires internationales, de l'Immigration et des Communautés culturelles. Québec: Direction générale des politiques et programmes d'inégration linguistique, Service du développement pédagogique.

Hirsch, E.D., Jr. (1987). Cultural literacy: What every American needs to know. New York: Houghton Mifflin.

Kymlicka, W. (1992). Recent work in citizenship theory. Report for Corporate Policy and Research, Multiculturalism and Citizenship Canada, Ottawa.

LeBlanc R. (1989). La pluralité des démarches et des pratiques: magma informe ou épuration progressive. Bulletin de l'AQEFLS, 11(1), 2-16.

LeBlanc, C., Courtel, C., \& Trescases, P. (1990). Étude nationale sur les programmes de français de base-Le syllabus culture. Winnipeg: ACPLS et Éditions M.

Ministry of Citizenship and Culture. (1989). ESL and citizenship: Theme issue of TESL Talk. TESL Talk, 19(1).

Ministry of Education and Training. (1995). The common curriculum: Policies and outcomes, grades 1-9. Toronto, ON: Queen's Printer.

Morasse, C. (1995). La composante culturelle en enseignement des langues secondes. Unpublished paper, Faculty of Education, University of Ottawa.

Nora, P. (1984). Les lieux de mémoire: La république. Paris: Gallimard.

Orr, J., \& Finney, S. (1995). Making cross-cultural education meaningful through face-to-face experiences. Journal of Professional Studies, 3(1), 29-38.

Owens, R., \& Steinhoff, C. (1989). Towards a theory of organizational culture. Journal of Educational Administration, 27(3), 6-16.

Schein, E.H. (1985). Organizational culture and leadership. San Francisco, CA: Jossey-Bass.

Seelye, N.H. (1984). Teaching culture: Strategies for foreign language educators. Skokie, IL: National Text Book Company.

York, S.L. (1991). Roots and wings: Affirming culture in early childhood programs. St. Paul, MN: Redleaf Press.

York, S.L. (1992). Developing roots and wings: A trainer's guide to affirming culture in early childhood programs. St. Paul, MN: Redleaf Press.

$\mathrm{Xu}, \mathrm{F}-\mathrm{Y}$. (1994). Investigating the selection criteria and procedures concerning the English language readiness of foreign trained teachers in a professional upgrading program: An ethnographic study. Unpublished report, Faculty of Education, University of Ottawa. 